\title{
Perbandingan Metode Script Dan Keyframe Pada Pembuatan Animasi Tiga Dimensi
}

\author{
Moh Taufik H ${ }^{1)}$, M.Suyanto ${ }^{2}$, Hanif Al Fatta ${ }^{3)}$ \\ Universitas Amikom Yogyakarta \\ Jl. Ring Road Utara, Ngringin, Condongcatur, Kec. Depok, Kabupaten Sleman, \\ Daerah Istimewa Yogyakarta \\ 1'moh.1093@students,amikom.ac.id, ${ }^{2}$ yanto@amikom.ac.id, ${ }^{3 h}$ hanif.a@amikom.ac.id
}

\begin{abstract}
Abstrak
Pada perkembanganya industri animasi sangat banyak permintaan dalam proses pembuatanya dari bahan dan proses, animasi dibagi menjadi dua yaitu animasi dua dimensi dan tiga dimensi ada banyak macam pembuatan animasi tiga dimensi, stop-motion, cut-out, motion capture, puppet, claymotion, keyframe, dan script. Saat ini animator 3D masih menggunakan teknik keyframe dan script.Pada perbandigngan ini bertujuan untuk mengetahui metode mana yang lebih tepat untuk membuat animasi tiga dimensi dengan tanpa jeda, file yang lebih kecil.
\end{abstract}

Kata kunci:Animasi 3 Dimensi, Script, Keyframe

\section{PENDAhULUAN}

Dalam perkembanganya animasi 3D atau yang disebut animasi 3 Dimensi sudah sangat marak untuk berbagai kebutuhan industri, seperti motion grafis, industri periklanan, instalasi seni, pembuatan game, hingga keperluan simulasi, dan berbagai macam sektor ekonomi kreatif lainya. Selanjutnya dari materi atau bahan dasar animasi dapat dikatagorikan menjadi dua macam jenis animasi, film animasi dwi marta (flat animation) dan film animasi tri marta (objek animation) (Syahfitri, 2011)

Banyak macam model animasi 3D saat ini digunakan untuk berbagai maksud dan tujuan. Dalam pembuatan animasi terdapat berbagai jenis metode pembuatan seperti stopmotion, cut-out, motion capture, puppet, claymotion, keyframe, dan script. Saat ini animator 3D masih menggunakan teknik keyframe dan script.

Keyframe dalam animasi dimulai dengan membuat sebuah point awal kepoint akhir sebuah animasi (Putra Wisara, 2018). Script adalah metode editing dengan cara memasukan naskah yang berupa Bahasa Python ke dalam frame untuk mengatur nilai (value) suatu objek (property). Pada setiap metode memiliki kelebihan dan kelemahan pada proses editing. Dalam pembuatan animasi 3D menggunakan metode keyframe, seperti pembuatan animasi perulangan gerak memerlukan banyaknya keyframe yang tentunya akan memakan banyak waktu dan ukuran file menjadi besar. Sedangkan menggunakan metode script tidak semua gerak animasi dapat diterapkan.

\section{METODE PENELITIAN}

Metode yang penulis gunakan dalam penelitian ini adalah metode Research And Development (R\&D). Research And Development adalah suatu penelitian dimana alat yang telah dibuat akan diuji cobakan dan dilihat keefektifannya (Hasibuan, 2007).

Riset pengembangan atau Research and Development bertujuan untuk mengembangkan, menguji kemanfaatan dan efektifitas produk (model) yang dikembangkan, baik produk teknologi, material, organisasi, metode, alat-alat dan sebagainya. Sebagai riset terapan,riset pengembangan bertujuan bukan untuk untuk menghasilkan teori. Oleh karena itu, dalam penelitian pengembangan sangat dimungkinkan untuk menggunakan multi pendekatan atau multi metode (Jaedun, 2011).

\section{TINJAUAN PUSTAKA}

Pembuatan Model Gerakan Animasi 2D Dengan Menggunakan Metode Inverse Kinematik, Heru Setiya, 2015. Penelitian ini menghasilkan empat gerakan yang dapat diterapkan kedalam setiap karakter animasi. 
Pada proses pengujian, setiap gerakan dapat diterapkan secara baik ke dalam masingmasing karakter. Pada model gerakan berjalan, peneliti membuat delapan keyframe dengan setiap keyframe memiliki panjang 3 frame. Berbeda dengan model gerakan berlari, pada gerakan berlari menggunakan duabelas keyframe. Penggunaan keyframe yang lebih banyak tersebut untuk memberikan efek gerakan yang lebih halus. Hal tersebut juga penulis terapkan pada model gerakan melompat dan mengendap- endap. Pada gerakan melompat, penulis mengawali dengan gerakan berlari dahulu. Hal tersebut akan membuat gerakan terlihat semakin nyata. Hasil dari penelitian ini, model gerakan dapat diterapkan ke dalam setiap karakter secara otomatis dengan cara mengimpor model gerakan ke dalam skeleton effect (Heru, 2015).

Pembuatan Film Animasi 2D Menggunakan Metode Keyframe Berjudul "Kancil dan Siput", Angga Firmansyah, 2013. Membuat animasi 2D frame dengan metode frame menggunakan Adobe Flash yang kemudian dikombinasikan dengan background image. Animasi menceritakan tentang kelinci dan bekicot Siput saat menghadapi situasi sulit dan memanfaatkan lingkungan sekitarnya sehingga bisa melatih kekritisan anak, bahwa dalam kondisi buruk apapun pastinya bisa dipikirkan memadamkan gagasan sebagai alat untuk menyelesaikan sebuah Masalah sementara rusa menggambarkan bahwa kebanggaan akan membawa kehancuran pada dirinya sendiri dan kelangkaannya merugikan dirinya sendiri. Proses pembuatan animasi dilakukan dengan beberapa tahap pra produksi, produksi hingga pasca produksi (Angga, 2013).

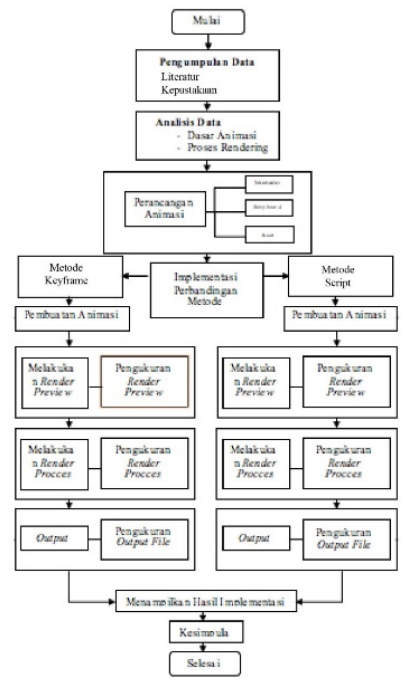

Tabel 1. Alur Penelitian

\section{HASIL DAN PEMBAHASAN}

Dari hasil uji rendering dan uji gerakan terdapat kelebihan dan kelamahan perbandingan metode keyframe dan script dalam proses editing animasi tiga dimensi dari penelitian sebelumnya.

Pada metode keyframe lebih mudah karena tidak perlu memasukan source code pada library karena tersedia pada menu untuk menggerakan object

Pada metode script perlu usaha untuk memasukan source code kedalam library namun pada beberapa scene hasil yang dihasilkan memiliki kualitas lebih ringan/kecil.

\section{PENUTUP}

\section{a. Kesimpulan}

Pada dasarnya beberapa scene untuk ukuran file bisa lebih kecil menggunakan metode script, tapi keyframe juga diperlukan untuk mempercepat pekerjaan pada scene scene tertenu.

\section{b. Saran}

Untuk penelitian selanjutnya, dapat melajutkan dengan model simulasi, dan menggunakan software yang lain.

\section{REFERENSI}

Firmansyah, Angga. (2013). Pembuatan Film Animasi 2D Menggunakan Metode Frame by Frame Berjudul "Kancil dan Siput”, Jurnal ilmiah Dasi. 
Syahfitri, Yunita. (2011). Teknik Film Animasi Dalam Dunia Komputer, Jurnal SAINTIKOM.

Hasibuan, Zainal A. (2007). Metodologi Penelitian Pada Bidang Ilmu Komputer Dan Teknologi Informasi, Fakultas Ilmu Komputer, Inuversitas Indonesia

M. Suyanto. (2005). Multimedia Alat Untuk Meningkatkan Keunggulan Bersaing. Yogyakarta: Andi Offset

Nugraha, Heru S. (2015). Pembuatan Model Gerakan Animasi 2D Dengan Menggunakan Metode Inverse Kinematik, Journal OJK. 